\title{
Forb and shrub effects on ruminal fermentation in cattle
}

\author{
DAVE ARTHUN, J.L. HOLECHEK, J.D. WALLACE, M.L. GAYLEAN, AND \\ M. CARDENAS
}

Authors are graduate research assistant and professor, Dept. of Animal and Range Sci., New Mexico State Univ., Las Cruces; and professor, Dept. of Exp. Stat., New Mexico State Univ., Las Cruces 88003.

\section{Abstract}

One experiment involving steers fed low-quality grass diets singly and mixed with native forbs, native shrubs, or alfalfa (Medicago sativaL.) was conducted to compare the influence of these diets on ruminal fermentation. Native forbs used in our study were a 50:50 mixture of scarlet globemallow (Sphaeralcea coccinea Nutt.) and leatherleaf croton (Croton pottsii Lam.); native shrubs were a 50:50 mixture of fourwing saltbush (Atriplex canescens [Pursh.] and mountain mahogany (Cercocarpus montanus Raf.). Neither passage rate of indigestible neutral detergent fiber nor fluid passage rate differed $(P>.10)$ among the 4 diets. Ruminal $\mathrm{pH}$ did not differ $(P>10)$ among diets, and ruminal ammonia concentrations differed $(P<.10)$ inconsistently among diets, depending on time after feeding. Likewise, total ruminal volatile fatty acid (VFA) concentrations did not differ $(P>.10)$ among diets. Except for butyrate [less $(P<.05)$ with alfalfa], proportions of individual VFA showed little difference among diets. Based on these data, adding forbs or shrubs with low-quality forage diets appears to elicit few changes in ruminal digesta kinetics and fermentation patterns compared to including alfalifa hay.

Key Words: rangelands, ruminants, nutrition, forages, native shrubs

There is considerable evidence that including forbs and shrubs in cattle diets improves cattle performance during periods when grasses are dormant and low in quality (Holechek et al. 1989a). Several studies reviewed by Holechek et al. (1989a) show that leaves from forbs and shrubs contain more protein, phosphorus, and cell solubles than do grasses at comparable stages of maturity. In recent digestion trials with cattle (Arthun et al. 1992), goats (Hunez-Hernandez et al. 1989), and sheep (Rafique et al. 1992), forage intake and nitrogen retention did not differ between palatable range shrubs and alfalfa (Medicago sativa $\mathrm{L}$.) hay fed mixed into low-quality grass diets. However, these studies did not evaluate comparative ruminal fermentation characteristics of the shrub and alfalfa diets.

Our objectives were to determine passage rate of indigestible, fiber, fluid passage rate, ruminal $\mathrm{pH}$, ruminal ammonia $\left(\mathrm{NH}^{3}\right)$ concentrations, and ruminal volatile fatty acid (VFA) proportions in beef steers fed a low-quality grass diet singly and in combination with forbs, shrubs, and alfalfa hay. Forbs and shrubs used in our study are common range components in New Mexico, and their use by cattle is well documented. Results from our study should provide a better understanding of how native range forbs and shrubs influence range cattle nutritional status.

Journal Article 1626 of the New Mexico Agr. Exp. Sta., Las Cruces.

Manuscript accepted 4 Apr. 1992.

\section{Materials and Methods}

Four Angus $\times$ Hereford steers (average body weight $315 \mathrm{~kg}$ ), fitted with 10.2-cm ruminal cannulas, were used in a $4 \times 4$ Latin square experiment to evaluate ruminal fermentation and digesta kinetics when native forbs, native shrubs, and alfalfa were added to a basal diet of blue grama (Bouteloua gracilis [H.B.K.]) hay (blue grama; $1.21 \% \mathrm{~N}$ ) and barley straw (Hordeum vulgare $\mathrm{L}$.; .56\% $\mathrm{N}$ ). The basal diet was ground to pass a $2.5-\mathrm{cm}$ screen and to provide a $\mathrm{N}$ content of $1.04 \%$ on a dry matter basis $(70 \%$ blue grama, $30 \%$ straw). Forbs were a 50:50 mixture of actively growing scarlet globemallow (Sphaeralcea coccinea Nutt.) and leatherleaf croton (Croton pottsii [Klotzsch] Mudl. Arg.); shrubs were a 50:50 mixture of current year growth of fourwing saltbush (Atriplex canescens [Pursh.]) and mountain mahogany (Cercocarpus montanus Raf.). Mixtures (ground to pass a 2.5-cm screen) were used because of poor acceptance by cattle of diets comprised entirely of forbs and shrubs. Forbs, shrubs, or alfalfa (ALF) were mixed with components of the basal diet so that all 4 diets were isonitrogenous. Ingredient and chemical composition of diets used are shown in Table 1. Periods were 15 days, with collections occurring the last 5

Table 1. Ingredient and chemical composition of blue grama-barley straw diets with added alfalifa (ALF), forbs, or shrubs fed to beef steers.

\begin{tabular}{|c|c|c|c|c|}
\hline \multirow[b]{2}{*}{ Item } & \multicolumn{4}{|c|}{ Diets" } \\
\hline & Basal & $\begin{array}{l}\text { Basal } \\
+ \text { ALF }\end{array}$ & $\begin{array}{c}\text { Basal } \\
+ \text { forbs }\end{array}$ & $\begin{aligned} & \text { Basal } \\
+ & \text { shrubs }\end{aligned}$ \\
\hline $\begin{array}{l}\text { Ingredient }{ }^{\mathrm{b}} \\
\text { Blue grama hay } \\
\text { Barley straw } \\
\text { Alfalfa hay } \\
\text { Forbs } \\
\text { Shrubs }\end{array}$ & $\begin{array}{l}70.0 \\
30.0 \\
\square\end{array}$ & $\begin{array}{l}29.0 \\
58.0 \\
13.0 \\
\square\end{array}$ & $\begin{array}{l}26.0 \\
54.0 \\
20.0 \\
\end{array}$ & $\begin{array}{l}26.0 \\
54.0 \\
\overline{20.0}\end{array}$ \\
\hline \multicolumn{5}{|l|}{ Analysis $^{c}$} \\
\hline $\begin{array}{l}\mathrm{DM} \\
\mathrm{OM}^{d} \\
\mathrm{CP}^{\mathrm{d}} \\
\mathrm{NDF}^{\mathrm{d}} \\
\mathrm{ADF}^{\mathrm{d}} \\
\text { Acid detergent } \\
\text { insoluble } \\
\text { nitrogen }\end{array}$ & $\begin{array}{r}92.4 \\
90.0 \\
6.5 \\
72.9 \\
47.0\end{array}$ & $\begin{array}{r}92.4 \\
90.0 \\
6.5 \\
69.1 \\
44.8\end{array}$ & $\begin{array}{r}92.5 \\
90.0 \\
6.5 \\
67.7 \\
43.9\end{array}$ & $\begin{array}{r}92.4 \\
90.0 \\
6.5 \\
68.9 \\
43.8\end{array}$ \\
\hline
\end{tabular}

days. Steers were housed individually in an uninsulated barn $(0.69$ $\times 1.98 \mathrm{~m}$ pens) with free access to water, but no salt was provided. Intake was limited to $1.5 \%$ (OM basis) of body weight. Krysl et al. (1987) reported that OM intake by steers grazing dormant blue grama range averaged $1.49 \%$ of body weight.

Steers were individually fed their appropriate diet once daily $(0700)$. Fecal bags were used to collect total fecal output, and bags 
were changed twice daily. Feces from each steer were mixed thoroughly each day, and a $10 \%$ subsample was dried at $50^{\circ} \mathrm{C}$ in a forced-air oven, ground to pass a 2-mm screen, and composited by steer within period.

On day 1 of the collection period, $200 \mathrm{ml}$ of Co-EDTA (Uden et al. 1980) were dosed into the rumen just before the morning feeding. Pond et al. (1981) reported a dose $X$ meal interaction; therefore, all animals were dosed at the same time relative to feeding for each period. Ruminal samples $(250 \mathrm{ml})$ were taken at $4,8,12,24$, 32 , and 36 hours after dosing. The $\mathrm{pH}$ of digesta samples was measured (combination electrode), and samples were strained through 8 layers of cheesecloth. Strained ruminal fluid was acidified with $7.2 \mathrm{~N} \mathrm{H}_{2} \mathrm{SO}_{4}(1 \mathrm{ml} / 100 \mathrm{ml})$, frozen, and later analyzed for $\mathrm{Co}, \mathrm{NH}_{3}$, and VFA. On day 5 , at 4 hours after-feeding, the rumen of each steer was hand-evacuated, contents were weighed, mixed thoroughly, and a subsample taken, dried at $50^{\circ} \mathrm{C}$, ground to pass a 2-mm screen, and retained for later analyses.

Duplicate $8-\mathrm{cm} \times 16-\mathrm{cm}$ nylon bags (pore width $26 \pm 6 \mu \mathrm{m}$, length $42 \pm 5 \mu \mathrm{m}$ ) were suspended in the rumen on day 2 of the collection period to estimate in situ digestion. Nylon bags were filled with a 3-g sample (ground to pass a 2-mm screen) of the basal diet. Nylon bags devoid of forage served as blanks. All steers received 3 bags per incubation time (duplicate sample of basal diet plus 1 bank). Bags were retrieved after $0,6,12,24,48,72$, and 96 hours, then rinsed with tap water until rinse water was clear. Samples were dried at $50^{\circ} \mathrm{C}$ for 48 hours, weighed, and later assayed for residual neutral detergent fiber (NDF), (Goering and Van Soest, 1975).

\section{Laboratory Analyses}

Ruminal fluid samples were thawed at room temperature and centifuged at $10,000 \times G$ for $10 \mathrm{~min}$. Supernatant fluid was analyzed for Co by atomic absorption spectroscopy with an air-plusacetylene flame (McCollum and Galyean 1985) and for ammonia by the procedure of Broderick and Kang (1980). After adding 2-ethyl-butyric acid as an internal standard, fluid was recentrifuged at $10,000 \times \mathrm{G}$ for $10 \mathrm{~min}$, and VFA concentrations were analyzed by gas chromatography (Goetsch and Galyean 1983).

Fluid dilution rates were calculated by regressing the natural logarithm of Co concentrations against time. Ruminal fluid volume was calculated by dividing marker dose by marker concentration in the rumen at 0 hour.

Ruminal fill (collected 4 hours after feeding) and feed indigestible NDF (INDF) contents were determined using procedures described by Krysl et al. (1988). Ruminal fluid inoculum was from 2 steers fed ALF hay. Passage (Kp) of INDF was estimated by dividing INDF intake by INDF ruminal fill; division by 24 yields an estimate of passage per hour.

\section{Statistical Analyses}

Analysis of variance was conducted using GLM procedures of SAS (1984). Digesta flow and ruminal fill data were analyzed with a model that included treatment (diets), period, and animal as sources of variation. Preplanned orthogonal contrasts were made between forbs and shrubs. If forbs and shrubs were different $(P<.10)$, means were separated by the least significance difference method. If forbs and shrubs did not differ $(P>.10)$, they were contrasted with ALF. If no differences $(P>.10)$ were observed, forbs, shrubs, and ALF were contrasted with the basal diet. If ALF differed $(P<.10)$ from forbs and shrubs, ALF was contrasted with the basal diet. Nonlinear regression analysis was used to analyze in situ nylon bag rate of disappearance data (Mertens and Loften 1980). Percentage NDF remaining at each incubation time and disappearance rate were analyzed with the same model as digesta flow and fill data. Ruminal fermentation measurements $\left(\mathrm{pH}, \mathrm{NH}_{3}\right.$, and VFA) were analyzed as a split-plot design, with a Latin square arrangement as the main plot, and time and associated interactions with main-plot factors as the subplot. The Latin square error was used to test main-plot effects, and the residual was used to test sub-plot effects.

\section{Results and Discussion}

\section{Passage Rate}

Estimates of ruminal INDF passage rate did not differ $(P>.10)$ among diets (Table 2). Our values were considerably less than

Table 2. Ruminal indigestible neutral detergent fiber passage and fluid dilution rate in steers fed a low-quality basal forage diet with or without forbs, shrubs, or alfalfa.

\begin{tabular}{|c|c|c|c|c|c|}
\hline Item & $\begin{array}{l}\text { Basal } \\
\text { diet }\end{array}$ & $\begin{array}{c}\text { Basal } \\
+ \text { ALF } \\
\text { diet }\end{array}$ & $\begin{array}{c}\text { Basal } \\
+ \text { forbs } \\
\text { diet }\end{array}$ & $\begin{array}{c}\text { Basal } \\
+ \text { shrubs } \\
\text { diet }\end{array}$ & $\mathbf{S E}^{\mathbf{a}}$ \\
\hline $\begin{array}{l}\text { INDF passage, } \\
\% / \text { hour }\end{array}$ & 1.1 & 0.9 & 1.0 & 1.0 & 0.10 \\
\hline $\begin{array}{l}\text { Particulate turnover } \\
\text { time, hour }\end{array}$ & 90.9 & 111.1 & 100.0 & 100.0 & 2.60 \\
\hline $\begin{array}{l}\text { Fluid dilution rate, } \\
\% / \text { hour } \\
\text { Fluid volume, liters }\end{array}$ & $\begin{array}{r}7.0 \\
39.1\end{array}$ & $\begin{array}{r}6.1 \\
45.4\end{array}$ & $\begin{array}{r}6.6 \\
38.2\end{array}$ & $\begin{array}{r}8.1 \\
32.3\end{array}$ & $\begin{array}{l}0.88 \\
8.4\end{array}$ \\
\hline
\end{tabular}

an $=4$.

those reported by Krysl et al. (1987), who summarized the results of 20 trials with cattle grazing blue grama rangelands in southcentral New Mexico. In their study, cattle grazing dormant and actively growing rangelands had an average $\mathrm{Kp}$ of $3.1 \% /$ hour and $3.8 \% /$ hour, respectively. The lower passage values reported in our study may reflect forage differences, but more likely are a function of different techniques.

Rare-earth labeling techniques used to estimate particulate passage typically yield faster passage rates than techniques like ours that rely on measurement of indigestible forage components. For example, Del Curto et al. (1990) reported indigestible ADF-based passage estimates of approximately $2 \%$ / hour in steers fed tallgrassprairie forage plus supplement (1.5\% of body weight); these values are intermediate between our INDF-based estimate and those of Krysl et al. (1987). Rare earth-labeling techniques like those used by Krysl et al. (1987) are subject to migration of the marker from originally labeled particles to small feed particles and bacteria (Combs et al. 1992). Hence, faster passage rate estimates might be expected with rare-earth-labeled forage than with a technique based on fill of an indigestible forage component. In addition, our technique assumes steady-state conditions (constant ruminal fill), which is not likely the case in limit-fed ruminants fed once daily.

Fluid dilution and volume did not differ $(P>.10)$ among treatments (Table 3$)$. Fluid dilution rate $(\% / \mathrm{h})$ was similar to values reported by McCollum and Galyean (1985) in steers fed prairie hay ( $1.69 \%$ of body weight), but less than in other studies where steers consumed similar diets, but at higher intakes (Funk et al. 1987).

\section{Ruminal Ammonia and pH}

Treatment means for $\mathrm{NH}_{3}$ concentration were analyzed within sampling times because of a treatment by sampling time interaction $(P<.10)$. Differences among treatments were noted at 4 hours after feeding, with less $(P<.05) \mathrm{NH}_{3}$ with the ALF diet than for the basal diet (Table 3). At 8 hours after feeding, the shrub diet had a lower $(P<.10) \mathrm{NH}_{3}$ concentration than the other 3 diets. Ruminal $\mathrm{NH}_{3}$ concentrations peaked 24 hours after feeding for the basal diet, 8 hours for basal plus forbs and 12 hours for the ALF and shrub diets. Ruminal $\mathrm{NH}_{3}$ concentrations ranged from 2.3 to 6.2 $(\mathrm{mg} / 100 \mathrm{ml}$ ), which agrees with reported values for cattle consuming similar diets (Funk et al. 1987, Krysl et al. 1987). 
Table 3. Ruminal ammonia concentration $(\mathrm{mg} / 100 \mathrm{ml})$ in steers fed a low-quality basal forage with or without alfalia, forbs, or shrubs.

\begin{tabular}{|c|c|c|c|c|c|}
\hline \multirow[b]{2}{*}{$\begin{array}{l}\text { Sampling } \\
\text { time }\end{array}$} & \multicolumn{4}{|c|}{ Diet $^{a}$} & \multirow[b]{2}{*}{$S E^{f}$} \\
\hline & Basal & $\begin{array}{l}\text { Basal } \\
+ \text { ALF }\end{array}$ & $\begin{array}{l}\text { Basal } \\
+ \text { forbs }\end{array}$ & $\begin{array}{r}\text { Basal } \\
+ \text { shrubs }\end{array}$ & \\
\hline (Hour) & \multicolumn{5}{|c|}{$\ldots(\mathrm{mg} / 100 \mathrm{ml})-\ldots$} \\
\hline 0 & 4.6 & 5.0 & 3.1 & 3.2 & .7 \\
\hline 4 & $5.2^{\mathrm{d}}$ & $2.9^{\circ}$ & $4.2^{\mathrm{de}}$ & $4.2^{\mathrm{de}}$ & .8 \\
\hline 8 & $5.1^{\mathrm{b}}$ & $6.1^{\mathrm{b}}$ & $5.4^{\circ}$ & $2.3^{c}$ & .7 \\
\hline 12 & 4.8 & 6.2 & 5.2 & 5.2 & .8 \\
\hline
\end{tabular}

${ }^{\mathrm{a}} \mathrm{Basal}=70 \%$ blue grama hay, $30 \%$ barley straw, ALF = alfalfa, forbs = 50:50 mixture of scarlet globemallow and leatherleaf croton, shrubs = 50:50 mixture of fourwing saltbush and mountain mahogany.

$b, c$ Row means that do not have common superscripts differ $(P<.05)$.

d,e Row means that do not have common superscripts $(P<.10$. $\mathrm{n}=4$.

Slyter et al. (1979) suggested a minimum of $2.2 \mathrm{mg} / 100 \mathrm{ml}$ of $\mathrm{NH}_{3}$ for optimum microbial protein synthesis. Maximum microbial growth, however, required 3 to $5 \mathrm{mg} / 100 \mathrm{ml}$ (Satter and Slyter 1974). Ruminal $\mathrm{NH}_{3}$ concentrations in the present experiment appear to be within the range for optimum microbial growth. Because of experimental constraints (e.g., fixed intake and isonitrogenous diets), large fluctuations in $\mathrm{NH}_{3}$ concentrations were not anticipated.

Ruminal pH did not differ $(P>.10)$ among diets. Because no treatment by sampling time interaction was detected $(P>.10)$, means were pooled across sampling time. Ruminal $\mathrm{pH}$ had an overall mean of 6.6, which agrees closely with previous research for cattle consuming similar diets (McCollum et al. 1985, Krysl 1986, Funk et al. 1987, Caton 1987, Freeman 1987). Hoover et al. (1984) reported a pH of 6.5 was optimal for fiber and OM digestion. A generally accepted range of 6.2 to 7.0 for grazing ruminants has been suggested by $Q$ rskov (1982), with pH values below 6.2 resulting in inhibited cellulolytic bacterial growth. Hence, the $\mathrm{pH}$ values in our study fall within the optimum range for OM digestion and microbial growth.

\section{Ruminal VFA}

Total ruminal VFA concentrations did not differ $(P>.10)$ among treatments averaged over all sampling times (Table 4). A

Table 4. Ruminal total VFA concentration and molar proportions of acetute, propionate, butyrate, valerate, isovalerate, and isobutyrate in steers fed a low-quality basal forage with or without alfalfa, forbs, or shrubs.

\begin{tabular}{|c|c|c|c|c|c|}
\hline \multirow[b]{2}{*}{ Item } & \multicolumn{4}{|c|}{ Diet" } & \multirow[b]{2}{*}{$S E^{f}$} \\
\hline & Basal & $\begin{array}{l}\text { Basal } \\
+ \text { ALF }\end{array}$ & $\begin{array}{l}\text { Basal } \\
\text { + forbs }\end{array}$ & $\begin{array}{r}\text { Basal } \\
+ \text { shrubs }\end{array}$ & \\
\hline \multirow[t]{2}{*}{ Total, $\mathrm{mM}^{\mathrm{e}}$} & 67.0 & 67.0 & 64.9 & 64.5 & 4.6 \\
\hline & --- & $-\mathrm{mol} / \mathrm{lo}$ & mol - & $=---$ & \\
\hline Acetate $^{\circ}$ & 72.4 & $73.4^{\prime}$ & 72.4 & 72.7 & .5 \\
\hline Propionate $^{e}$ & 17.9 & 18.3 & 18.3 & 18.0 & .4 \\
\hline Butyrate $^{e}$ & $8.0^{d}$ & $6.7^{\mathrm{c}}$ & $7.6^{\mathrm{d}}$ & $7.7^{\mathrm{d}}$ & .2 \\
\hline Valerate $^{e}$ & .41 & .45 & .43 & .43 & .03 \\
\hline Isovalerate ${ }^{\bullet}$ & .65 & .58 & .60 & .64 & .08 \\
\hline Isobutyrate" & .58 & .58 & .56 & .54 & .06 \\
\hline
\end{tabular}

Basal $=70 \%$ blue grama hay, $30 \%$ barley straw, ALF $=$ alfalfa, forbs $=50: 50$ mixture of scarlet globemallow and leatherleaf croton, shrubs $=50: 50$ mixture of fourwing saltbush and mountain mahogany.

${ }_{b, c, d}$ Row means that do not have common superscripts differ $(P<.05)$.

"Values are means averaged over 7 times $(0,4,8,12,24,32$, and 36 hours) after feeding $(P>.10)$; no treatment $X$ sampling time interaction.

$t_{n}=28$. treatment $X$ sampling time interaction was not detected $(P>.10)$. Rafique (1988) also found no treatment effects on total VFA when sheep were fed the same diets as in our study. Freeman (1987), who fed steers a diet similar to the one in the present study [prairie hay (Agropyron spp.); 5.9\% CP], reported no treatment effects on total VFA when prairie hay was supplemented with 20 or $40 \% \mathrm{CP}$ supplements. Pordomingo (1989) reported that total VFA concentrations were not altered when steers grazing summer blue grama rangeland were supplemented with whole-shelled corn. Holechek et al. (1989b) observed no differences in in vitro total VFA concentrations between grasses, forbs, and shrubs (collected from rangeland in eastern New Mexico) when incubated with inoculum from steers consuming a diet of prairie-grass hay.

Ruminal proportions of acetate did not differ $(P>.10)$ among treatments. Greater proportions of acetate are often associated with decreased forage quality because acetate is an end-product of cell wall fermentation (Van Soest 1982). Similarly, Rafique (1988) reported no differences in acetate proportions with sheep fed the same diets used in our experiment. Ruminal propionate molar proportions also did not differ $(P>.10)$ among treatments. Propionate tends to increase relative to acetate as forage quality increases because propionate is an end-product of cell soluble fermentation. Legumes and forbs typically contain more cell soluble than do grasses; however, in our study, the slightly greater cell wall content of the basal forage than of mixtures was evidently not enough to alter molar proportions of acetate or propionate.

Basal plus ALF had the least $(P<.01)$ butyrate molar proportions, with no differences among the other 3 diets. Butyrate, like propionate, is associated with higher forage quality, (primarily greater CP; Topps et al. 1965, McCollum et al. 1985, Krysl 1986, Pordomingo 1989). Decreased molar proportions of butyrate in the ALF diet are perplexing. Rafique (1988) found butyrate levels to be equal among the same diets when fed to sheep. Minor acids (valerate, isovalerate, isobutyrate; Table 4) did not differ among treatments. Caton (1987) reported no differences in minor VFA in protein supplemented and nonsupplemented steers grazing dormant blue grama range.

\section{Digestibility}

In situ rate of NDF disappearance from nylon bags did not differ $(P>.10)$ among treatments (Table 5). These results agree with

Table 5. In situ NDF disappearance and rates of disappearance of basal forage at various incubation times in steers fed a low-quality basal forage with or without alfalf, forbs, or shrubs.

\begin{tabular}{|c|c|c|c|c|c|}
\hline \multirow[b]{2}{*}{$\begin{array}{l}\text { Incubation } \\
\text { time }\end{array}$} & \multicolumn{4}{|c|}{ Diet $^{\mathbf{a}}$} & \multirow[b]{2}{*}{$\mathbf{S E}^{1}$} \\
\hline & Basal & $\begin{array}{l}\text { Basal } \\
+ \text { ALF }\end{array}$ & $\begin{array}{c}\text { Basal } \\
+ \text { forbs }\end{array}$ & $\begin{aligned} & \text { Basal } \\
+ & \text { shrubs }\end{aligned}$ & \\
\hline (Hour) & \multicolumn{5}{|c|}{$-\ldots-\ldots \ldots-\ldots$ (units) $-\ldots \ldots$} \\
\hline 6 & 90.7 & 90.3 & 92.6 & 81.4 & 4.9 \\
\hline 12 & $91.6^{\mathrm{b}}$ & $87.8^{b c}$ & $87.0^{\mathrm{bc}}$ & $78.3^{\mathrm{c}}$ & 3.4 \\
\hline 24 & 78.4 & 73.7 & 75.8 & 76.6 & 5.0 \\
\hline 48 & 63.0 & 47.8 & 60.1 & 54.5 & 6.7 \\
\hline 72 & 54.6 & 51.0 & 47.1 & 41.9 & 6.5 \\
\hline Disappearance rate, & & & & & \\
\hline of ither & 3.7 & 3.1 & 3.0 & 2.8 & .57 \\
\hline
\end{tabular}

"Basal $=70 \%$ blue grama hay, $30 \%$ barley straw, $A L F=$ alfalfa, forbs $=50: 50$ mixture of scarlet globemallow and leatherleaf croton, shrubs $=50: 50$ mixture of fourwing saltbush and mountain mahogany.

${ }_{b, c}$ Means in the same row with different letters in their superscripts differ $(P<.05)$, $d_{n}=4$.

McCollum and Galyean (1985), who observed no overall differences among in vitro rates of DM disappearance with change in percentage of dietary forbs with beef steers grazing blue grama 
range. These workers did note, however, that diets that had more forbs (17 vs $77 \%$ ) were digested to a greater extent at 4 hours incubation. In our data, in situ NDF remaining at 12 hours was greater $(P<.05)$ for the basal diet $(91.6 \%)$ than for basal-plusshrub diet (78.3\%); ALF and forb diets were intermediate.

No differences in NDF remaining were observed at other incubation times. No differences $(P>.10)$ were observed for in vivo DM or OM digestibilities among diets (Arthun et al. 1992). In vivo OM digestibility values were $63.8,56.8,63.2$, and 63.5 for basal, ALF, basal-plus-forbs and basal-plus shrubs diets, respectively.

\section{Conclusions}

Scarlet globemallow, leatherleaf croton, fourwing saltbush, and mountain mahogany are important botanical components on many ranges in New Mexico and other western states. Consumption by cattle of these plants, particularly when grasses are dormant, is well documented. A recent study (Arthun et al. 1992) showed that these plants are excellent sources of $\mathrm{N}$ for cattle consuming low-quality grass diets. In our study, including these forbs and shrubs in low-quality grass diets had a similar effect on ruminal fermination as did inclusion of alfalfa. No toxicity problems were observed in any of our trials. Passage rate of indigestible $\mathrm{NDF}$, fluid passage rate, ruminal ammonia concentration, ruminal $\mathrm{pH}, \mathrm{NDF}$ digestion rate, and total VFA concentration (also molar proportions) were used as measures of ruminal fermentation in our study.

\section{Literature Cited}

Arthun, D., J.L. Holechek, J.D. Wallace, M.L. Galyean, M. Cardenas, and S. Rafique. 1992. Forb and shrub influences on steer nitrogen retention. J. Range Manage.

Broderick, G.A., and J.H. Kang. 1980. Automated simultaneous determination of ammonia and total amino acids in ruminal fluid and in vitro media. J. Dairy Sci. 33:64-67.

Caton, J.S. 1987. Influence of protein supplementation on ruminal and cecal fermentation and digesta kinetics in steers grazing dormant blue grama rangeland and sheep fed low-quality hay. Ph.D. Diss. New Mexico State Univ., Las Cruces.

Combs, D.K., R.D. Shaver, and L.D. Satter. 1992. Retention of rare earths by hay particles following incubation in fresh or autoclaved rumen fluid. J. Dairy Sci. 75:132-139.

DelCurto, T., R.C. Cochran, D.L. Harmon, A.A. Beharka, K.A. Jacques, G. Tocone, and E.S. Vanzant. 1990. Supplementation of tallgrass-prairie forage: 1. Influence of varying supplemental protein and(or) energy levels on forage utilization characteristics of beef steers in confinement. J. Anim. Sci. 68:515-531.

Freeman, A.S. 1987. Effects of protein and energy supplementation on intake, digestibility, ruminal fermentation and digesta kinetics in beef steers fed low-quality prairie hay. Ph.D. Diss. New Mexico State Univ., Las Cruces.

Funk, M.A., M.L. Galyean, M.E. Branine, and L.J. Krysl. 1987. Steers grazing blue grama rangeland throughout the growing season. I. Dietary composition, intake, digesta kinetics and ruminal fermentation. J. Anim. Sci. 65:1342-1348.
Goering, H.K., and P.J. Van Soest. 1975. Forage fiber analyses (apparatus, reagents, procedures, and some applications). Agr. Handb. 739, ARS USDA, Washington, D.C.

Goetsch, A.L., and M.L. Galyean. 1983. Influence of feeding frequency on passage of fluid and particulate markers in steers fed a concentrate diet. Can. J. Anim. Sci. 63:727.

Holechek, J.L., R.D. Pieper, and C.H. Herbel. 1989a. Range management principles and practices. Prentice-Hall, Inc. N.J.

Holechek, J.L., R.E. Estell, M.L. Galyean, and W. Richards. 1989b. Chemical composition, in vitro digestibility and in VFA concentrations of New Mexico native forages. Grass and Forage Sci. 44:101-107.

Hoover, W.H., C.R. Kincaid, G.A. Varga, W.V. Thayne, and L.L. Junkins, Jr. 1984. Effects of solids and liquid flow on fermentation in continuous cultures. IV. pH and dilution rate. J. Anim. Sci. 58:692-698.

Krysl, L.J. 1986. Influence of nitrogen fertilization on dietary botanical and chemical composition, intake and digesta kinetics of steers grazing blue grama rangeland. Ph.D. Diss. New Mexico State Univ., Las Cruces.

Krysl, L.J., M.L. Galyean, R.E. Estell, and B.F. Sowell. 1988. Estimating digestibility and faecal output in lambs using internal and external markers. J. Agr. Sci. (Camb.). 111:19-25.

Krysl, L.J., M.L. Galyean, J.D. Wallace, F.T. McCollum, M.B. Judkins, M.E. Branine, and J.S. Caton. 1987. Cattle nutrition on blue grama rangeland in New Mexico. New Mexico State Univ. Agr. Exp. Sta. Bull. 727.

McCollum, F.T., and M.L. Galyean. 1985. Influence of cottonseed meal supplementation on voluntary intake, rumen fermentation and rate of passage of prairie hay in beef steers. J. Anim. Sci. 60:570-577.

McCollum, F.T., M.L. Galyean, L.J. Krysl, and J.D. Wallace. 1985. Cattle grazing blue grama rangeland. I. Seasonal diets and rumen fermentation. J. Range Manage. 38:539-544.

Mertens, D.R., and J.R. Loften. 1980. The effect of starch on forage fiber digestion kinetics in vitro. J. Dairy Sci. 63:1437-1445.

Nunez-Hernandez, G., J.L. Holechek, J.D. Wallace, M.L. Galyean, A. Tembo, R. Valdez, and M. Cardenas. 1989. Influence of native shrubs on nutritional status of goats: nitrogen retention. J. Range Manage. 42:228-232.

Oskov, E.R. 1982. Protein nutrition of ruminants. Academic Press, N.Y.

Pond, K.R., A.G. Deswysen, J.H. Matis, G.T. Schelling, and W.C. Ellis. 1981. Rate of passage measurements as affected by dosing at beginning or end of a meal. J. Anim. Sci. 53 (Suppl. 1):724 (Abstr.).

Pordomingo, A.J. 1989. Effects of supplemental whole shelled corn on forage intake, digesta kinetics, ruminal fermentation and forage digestibility in beef steers grazing summer blue grama rangeland. M.S. Thesis. New Mexico State Univ., Las Cruces.

Rafique, S. 1988. Influence of forbs and shrubs on intake, digestibility, energy and nitrogen balance, ruminal fermentation and digesta kinetics in sheep fed low-quality forages. Ph.D. Diss. New Mexico State University, Las Cruces.

Rafique, S., J.D. Wallace, M.L. Galyean, D. Arthun, and J.L. Holechek. 1992. Influence of forbs and shrubs on ruminal fermentation and digestion kinetics in sheep fed a grass hay/straw diet. Small Ruminant Res. (in press).

SAS. 1984. SAS user's guide: Statistics: SAS Inst., Inc., Cary, N.C.

Satter, L.D., and L.L. Slyter. 1974. Effect of ammonia concentration on rumen microbial protein production in vitro. Brit. J. Nutr. 32:199-206.

Slyter, L.L., L.D. Satter, and D.A. Dinius. 1979. Effect of ruminal ammonia concentrations on nitrogen utilization by steers. J. Anim. Sci. 48:906-911.

Topps, J.H., W.C. Reed, and R.C. Elliot. 1965. The effect of season and of supplementary feeding on the rumen contents of African cattle grazing subtropical herbage II. $\mathrm{pH}$ values and concentrations and proportions of volatile fatty acids. J. Agr. Sci. (Camb.). 64:397-404.

Uden, P., P.E. Colucei, and P.J. Van Soest. 1980. Investigations of chromium, cerium and cobalt as markers in digesta. Rate of passage studies. J. Sci. Food Agr. 31:625-632.

Van Soest, P.J. 1982. Nutritional Ecology of the Ruminant. O and B Books, Corvallis, Ore. 